\title{
PARENTS TRANSMIT HAPPINESS ALONG WITH ASSOCIATED VALUES AND BEHAVIORS TO THEIR CHILDREN - A LIFELONG HAPPINESS DIVIDEND?
}

\author{
Bruce Headey \\ Melbourne Institute of Applied Economic and Social Research \\ University of Melbourne \\ Parkville \\ Australia 3052 \\ b.headey@unimelb.edu.au \\ Ruud Muffels \\ School of Social and Behavioral Sciences \\ Tilburg University \\ Netherlands \\ Ruud.j.Muffels@Tilburguniversity.edu
}

Gert G. Wagner

DIW

Mohrenstrasse 58

10117 Berlin

Germany

gwagner@diw.de

*Our thanks for valuable discussions about this paper to Alexander Wearing of Melbourne University, Stephen Headey of Monash University and Gisela Trommsdorff of the University of Konstanz. Thanks also to Simon Freiden and Markus Hahn of Melbourne Institute for assistance in preparing linked parent- 
child panel survey files. 


\begin{abstract}
There are strong two-way links between parent and child happiness (life satisfaction), even for 'children' who have grown up, moved to their own home and partnered themselves. German panel evidence shows that transmission of (un)happiness from parents to children is partly due to transmission of values and behaviors known to be associated with happiness (Headey, Wagner and Muffels, 2010, 2012). These values and behaviors include giving priority to prosocial and family values, rather than material values, maintaining a preferred balance between work and leisure, active social and community participation, and regular exercise. Both parents have about equal influence on the values and behaviors which children adopt. However, the life satisfaction of adult 'children' continues to be directly influenced by the life satisfaction of their mothers, with the influence of fathers being only indirect, via transmission of values and behaviors. There appears to be a lifelong happiness dividend (or unhappiness dividend) due to parenting.

Structural equation models with two-way causation indicate that the life satisfaction of offspring can significantly affect the satisfaction of their parents, as well as vice-versa, long after the 'children' have left home. Data come from 25 waves of the German Socio-Economic Panel Survey (SOEP, 1984-2008). SOEP is the only panel survey worldwide in which data on life satisfaction have been obtained from parents and an adequate sub-sample of children no longer living in the parental home.
\end{abstract}

KEY WORDS: life satisfaction; inter-generational transmission; German panel survey (SOEP) 


\section{PARENTS TRANSMIT HAPPINESS ALONG WITH ASSOCIATED VALUES AND BEHAVIORS TO THEIR CHILDREN - A LIFELONG HAPPINESS DIVIDEND?}

This paper is about the inter-generational transmission of happiness or life satisfaction (the terms will be used interchangeably). It is already well known that the life satisfaction levels of family members who live together are positively correlated (Headey, 1987; Winkelmann, 2004; Aguche and Trommsdorff, 2010; Schimmack and Lucas, 2010). Our contribution here is to show that there are still strong two-way links between the life satisfaction of parents and 'children' who have long since left the parental home, and in many cases, partnered themselves. As expected, these links are partly due to genetic personality traits. However, transmission of life satisfaction also appears to be due to parental modelling of specific values and behavioral choices, which we have previously shown to be associated with life satisfaction (Headey, Wagner and Muffels, 2010). These values and behaviors include giving priority to prosocial and family values, rather than material values, maintaining a preferred balance between work and leisure (work-life balance), active social and community participation, and regular exercise.

Most previous research on the life satisfaction of family members, like this paper, is based on the German Socio-Economic Panel Survey (SOEP) (Wagner, Frick and Schupp, 2007). SOEP is a household panel which began in 1984 (see the Methods section). Since then individuals aged 16 and over in sample households have being interviewed annually. So there are now 25 years of available data, including evidence of the life satisfaction of spouses and their children. Crucially for this paper, SOEP is the only available dataset worldwide, which asks questions about life satisfaction and provides an adequate sub- 
sample, not just of parents, but also of children who have left the parental home and now live separately.

Winkelmann (2004) was the first researcher using the German data to document substantial correlations between the life satisfaction levels of spouses, and also siblings, living in the same household. The sibling correlations are partly due to the fact that siblings have 50\% shared genes. Spouses, of course, do not share genes, but assortative mating partly accounts for the positive correlations between their levels of life satisfaction (Headey, Muffels and Wagner, 2010; Schimmack and Lucas, 2010). More specifically, men and women with traits positive for happiness (especially low neuroticism and high extroversion) tend to partner. However, it has also been shown that the happiness levels of partners covary over time, which presumably indicates the effects of life events and shared experiences (Powdthavee, 2008; Schimmack and Lucas, 2010).

It is well known that marital separation lowers the life satisfaction of both partners, with change initially occurring before the date of separation and getting worse afterwards (Campbell, Converse and Rodgers, 1976; Clark, Diener, Geogellis and Lucas, 2008). Curiously, men who happen to have higher levels of life satisfaction than their wives are at higher risk of marital break-up than average (Guven, Senik and Stichnoth, 2010). This could be due to the fact that it is quite common for men (but not women) to be quite satisfied with their marriages, and their lives-as-a-whole, a year or so before marital break-up (Headey, Harding and Warren, 2005). ${ }^{1}$ Another life event that lowers the life satisfaction of both partners is unemployment. It has been found that men's unemployment reduces, not just their own life satisfaction, but their wives' satisfaction as well (Winkelmann and Winkelmann, 1995). It also affects the

\footnotetext{
${ }^{1}$ It is also more common for women to be the immediate instigators of marital break-up than men (Headey, Harding and Warren, 2005).
} 
life satisfaction of their sons, but not apparently of their daughters (Kind and Haisken-DeNew, 2010). A spouse's long term illness is also likely to lower the life satisfaction of both partners, although some studies indicate that the caregiver spouse adapts and, in many cases, regains his/her previous level of satisfaction (Bookwala and Shulz, 1996; Ostwald, Godwin and Cron, 2009).

Up to now studies of the links between parent and child happiness appear to have focussed only on adolescent children living in the same household as their parents (Winkelman and Winkelman, 1995; Winkelmann, 2004; Aguche and Trommsdorff, 2010; Kind and Haisken-DeNew, 2010). Aguche and Trommsdorff (2010), using the SOEP data, found substantial correlations (0.300.45 ) between parent and child life satisfaction, and reported that, as expected, the links were partly due to inherited personality traits. High levels of life satisfaction in children were also due to supportive parenting and low levels of perceived conflict with parents. Interestingly, Aguche and Trommsdorff observed covariations over time in the panel data, so that when parents became happier (or unhappier), so did children. They reported that parental satisfaction mainly influenced child satisfaction, rather than vice-versa, although stronger reverse effects were found in families characterised by a high degree of parentchild conflict.

What has not been investigated, or shown before, is that the effects of parental life satisfaction persist after children leave the parental home. In some respects our findings are 'surprising' in that psychologists who study social networks routinely posit what is termed an 'axiom of distance'; the idea that people who do not live in close proximity usually have little effect on each other's feelings and perceptions (Bourgeois and Friedkin, 2001). Clearly, it is questionable whether, and if so how strongly, this axiom holds in the face of modern communications. 
The hypotheses which guided our empirical work are:

1. There are positive associations between the life satisfaction levels of both parents and their children even after the children have left the parental home.

2.1 The life satisfaction of both sons and daughters is more strongly linked to the life satisfaction of their mothers than their fathers.

2.2 The link between father and son life satisfaction is stronger than the link between father and daughter satisfaction.

3. The links between parent and child life satisfaction remain significant, net of the (partly) hereditary personality traits of neuroticism and extroversion.

4. The links between parent and child life satisfaction are partly due to transmission of values associated with happiness: pro-social values and family values.

5. The links are also partly due to transmission of behavioral choices associated with happiness: a preferred balance between work and leisure (work-life balance), active social participation and regular physical exercise.

Hypothesis 2.1 derives from evidence in child psychology that the emotional development of children is more strongly influenced by mothers than fathers, partly because it depends on close attachment and unconditional love from the mother in infancy (Bowlby, 1988; Gottman and Declaire, 1998). These findings relate particularly to self-esteem and the ability to form lasting intimate attachments, rather than to happiness, but it seems reasonable as a starting point for research to extrapolate them to happiness. A secondary hypothesis (hypothesis 2.2 here) is that, in so far as fathers are influential at all, they may act as role models for their sons, and so influence them more than daughters (Gottman and Declaire, 1998). 
The third hypothesis is a negative: we postulate that, even after 'children' have left home, the influence of their parents' happiness on their own happiness will not be solely due to (partly) genetic personality traits. In our statistical models testing this hypothesis, we include the personality traits of neuroticism and extroversion. These are the two traits most strongly associated with life satisfaction, and the two traits most clearly shown to be partly hereditary and stable in adulthood (Costa and McCrae, 1991). If hereditary personality traits do not entirely explain long term links between parent and child life satisfaction, what else may be involved? Our fourth and fifth hypotheses postulate that the links are partly due to values and behavioral choices modelled by parents. Previous research has shown that choices relating to values or life priorities are quite strongly related to happiness. In particular, individuals who give priority to pro-social (altruistic) values, and also to family values, are happier than those who prioritise material values (Emmons, 1986; Harlow and Cantor, 1996; Thoits and Hewitt, 2001; Nickerson et al, 2003; Diener and Seligman, 2004; Kasser and Kanner, 2004; Dunn, Aknin and Norton, 2008; Headey, 2008; Lyubomirsky, 2008; Headey, Muffels and Wagner, 2010; Headey, Muffels and Wagner, 2012).

In previous papers we have shown that three behavioral choices - maintaining a preferred work-life balance, the choice to be actively involved in social activities with friends and neighbours, and regular exercise - are significantly associated with happiness (Headey, Muffels and Wagner, 2010; Headey, Muffels and Wagner, 2012).

Welfare economics is based on the assumption that the main choice or trade-off which individuals make in trying to maximize their welfare or utility lies between work and other activities, including leisure (Little, 2002). Paid work is necessary to finance consumption, while other activities, particularly leisure 
time are assumed to be pleasurable. The validity of this trade-off assumption has rarely been directly tested, using life satisfaction measures, or what economists are now calling subjective measures of utility (Frey and Stutzer, 2002).

Another matter of individual choice is the extent to which one spends leisure time participating in social and community activities. There is abundant evidence that individuals with richer social networks or more social capital enjoy greater life satisfaction (Bradburn, 1969; Putnam, 2000; Diener and Diener, 2008). The panel data go beyond measuring static social networks and provide annual measures of frequency of social interaction with friends, relatives and neighbors. It is hypothesized that active, more frequent social participation is positively related to life satisfaction.

Another voluntary behavior which has been shown to be associated with life satisfaction is regular physical exercise (Diener, Suh, Lucas and Smith, 1999; Argyle, 2001). Here we investigate whether exercise habits are passed on from parents to children.

Overall, these hypotheses are based on the idea that parents model happy or unhappy living, along with associated values and behaviors. A key issue is whether the effects are long term, or even lifelong. Is there a long term (un)happiness dividend due to parenting?

\section{METHODS}

The German Socio-Economic Panel (SOEP) 1984-2008

The German (SOEP) panel began in 1984 in West Germany with a sample of 12541 respondents (Wagner, Frick and Schupp, 2007). Interviews have been conducted annually ever since. Everyone in the household aged 16 and over is 
interviewed. The cross-sectional representativeness of the panel is maintained by interviewing 'split-offs' and their new families. So when a young person leaves home ('splits off') to marry and set up a new family, the entire new family becomes part of the panel. The sample was extended to East Germany in 1990, shortly after the Berlin Wall came down, and since then has been boosted by the addition of new immigrant samples, a special sample of the rich, and recruitment of new respondents partly to increase numbers in 'policy groups'. There are now over 60,000 respondents on file, including a few grandchildren, as well as children of the original respondents. The main topics covered in the annual questionnaire are family, income and labour force dynamics. A question on life satisfaction has been included every year.

Most of the analysis in this paper is confined to parents and grown-up 'children' living separately from their parents. In all cases the children were originally included in the SOEP sample because they were living in their parents' household. Then they were followed and continued to be interviewed after they moved out. We use only cases for whom we have life satisfaction measures and also measures of personality traits for father and mother and 'child'. These restrictions are made because we want to compare the influence of fathers and mothers on, respectively, sons and daughters... so we need information about both parents. The reason for restricting the parent and child sub-samples to individuals for whom personality measures are available is that it is essential to net out the effects of (partly) hereditary personality traits on life satisfaction in order to estimate the effects of (what appears to be) parental modelling of life satisfaction and its associated values and behaviors. 
It would have been interesting to include a separate section on transmission of life satisfaction from single parents to their offspring. However, numbers were too low for structural equation modelling to be feasible. ${ }^{2}$

These various restrictions mean that the sub-samples used here cannot be regarded as fully representative of the national parent and child populations from which they are drawn. In particular the samples are biased towards intact families. Also the grown-up 'children' are relatively young, since only children who were still in the family home when first interviewed are included.

The total number of 'children' for whom life satisfaction and personality data are available is 3208 (1676 males and 1532 females). However, of these only 1251 (567 males and 684 females) were living separately from their parents in one or more survey years. The average age of the males in this group was 31.9 years (s.d. $=6.45$ ), ranging from 17 to 50 . The average age of females was 29.5 (s.d.=6.02), ranging from 18 to 50. Two-thirds were partnered, one-third were single.

The actual numbers of cases used in most of our analyses are much larger, because, as is common in panel research, data are pooled for all years combined, so that the cases are person-years. In other words, if an individual has been interviewed (say) 10 times - and provided life satisfaction and personality data - then that person counts 10 times in the analyses. A total of 32430 person-year cases (17327 males and 15203 females) are available for analysis.

\footnotetext{
${ }^{2}$ Only 64 daughters and 35 sons, who had been raised by single mothers for five or more years during their childhood and adolescence, were now living separately from their parents, and had provided necessary data on life satisfaction, traits, values and behaviors.
} 
It may be noted that the research reported here required construction of a special version of the SOEP file in which variables relating to fathers and mothers (life satisfaction etc) have been transposed on to the person-year case lines of their children. This is necessary in order to undertake statistical analyses showing, for example, associations between parent and child life satisfaction.

\section{Measures}

\section{Life satisfaction}

The dependent (outcome) variable in all equations is life satisfaction (mean=7.2 s.d.=1.6) measured on a 0-10 ('totally dissatisfied' to 'totally satisfied') scale. Single item measures of life satisfaction are plainly not as reliable or valid as multi-item measures, but are widely used in international surveys and have been reviewed as acceptably valid (Diener et al, 1999).

\section{Personality traits}

In 2005 for the first time SOEP included a short version of the Big Five Personality Domains - NEO-AC (Costa and McCrae, 1991). The traits in the Big Five are neuroticism, extroversion, openness, agreeableness and conscientiousness. Each trait was measured with just three items. However, the data managers report that the short version has proved satisfactorily reliable and valid, and has yielded trait measures which correlate highly with longer versions of the NEO-AC (Gerlitz and Schupp, 2005).

The two traits included in analyses in this paper are neuroticism and extroversion. It has long been known that these traits are quite strongly related to happiness (Costa and McCrae, 1980). There is also a great deal of work showing that neuroticism and extroversion are quite stable over a lifetime (Costa and McCrae, 1991; Roberts, Walton and Viechtbauer, 2006). The other 
three traits in the NEO-AC are less certainly related to happiness and there is less evidence about their stability (Lucas, 2008). ${ }^{3}$

It should be noted that, by including personality traits measured in 2005 on the right hand side of equations to account for life satisfaction in earlier as well as later years, we are in effect assuming that personality is completely stable. If it were completely stable, then of course it would not matter when it was measured. However, the assumption is not entirely correct. It is thought that ratings on personality traits might be changed to some degree by life experiences like having a stable marriage or an absorbing job (Roberts, Walton and Viechtbauer, 2006; Scollon and Diener, 2006).

\section{Values/life priorities}

It has proved difficult to develop valid measures of values or life priorities. Two pioneers of SWB research, Andrews and Withey (1976), reported that measures of values/life priorities asked on scales running from 'very important' to 'not at all important', appeared to suffer from social desirability bias, with almost all respondents giving high ratings to family values. Importance scores also had low test-retest reliability. A further possible problem was that importance scores and satisfaction scores in most life domains turned out to be moderately correlated. This might mean that people were quite good at getting what they wanted in life - a result in line with economists' utility maximization assumption - or might suggest some reverse causation, with respondents tending to impute importance to domains they were already well satisfied with, perhaps as a psychological mechanism to boost their overall life satisfaction (Andrews and Withey, 1976). In general, respondents whose life satisfaction was high tended to rate most domains as very important, whereas unhappy or

\footnotetext{
${ }^{3}$ Lucas (2008) notes that some studies report modest correlations between happiness and traits A and C. Trait O is usually found to be unrelated to happiness.
} 
depressed respondents tended (presumably as a consequence of unhappiness) to rate most domains as relatively unimportant. An underlying problem, which may partly account for measurement difficulties, is probably that most people are not of a philosophical bent and do not regularly think about their life priorities.

The German panel group decided to tackle these issues afresh and appears to have made considerable improvements in values measurement. Their approach is based on a classification of values initially developed by Kluckhohn and Strodtbeck (1961). They set out to measure three sets of values:

- pro-social values: friendship, helping others, social and political activism

- family values: marriage, children and the home

- material values: money and career success

Using this framework, the German research group developed survey items which have a stable factor structure and adequate test-retest reliability (Headey, 2008). Values have been measured intermittently (rather than annually) in SOEP, starting in 1990. The specific questions asked in different waves of the survey have varied somewhat; here we will use data from the 1990, 1992, 1995, 2004 and 2008 surveys in which questions were nearly identical. In these surveys 9 or 10 items were included ${ }^{4}$, all asked on a 1-4 scale running scale running from 'very important' to 'not at all important'. In each wave the items formed three distinct, replicating factors: a pro-social or altruistic values factor, a family values factor and a material values factor (Headey, 2008).

The pro-social values index gave equal weight to questions about the importance of 'being involved in social and political activities' and 'helping

\footnotetext{
${ }^{4}$ Ten items were included in 1990, 1992 and 1995 and then nine in 2004 and 2008. The item dropped in 2004 and 2008 related to the importance of having a wide circle of friends, which loaded on the pro-social factor.
} 
other people'. The family values index included items relating to the importance of a good marriage and having children. The material values index comprised items about 'being able to buy things', and 'success in your job'.

Behavioral choices: preferred versus actual working hours, active social participation and regular exercise

Each year the panel respondents are asked both how many hours per week they actually work (in all jobs combined, if they have more than one job), and how many they would prefer to work. The gap between these two figures can be treated as a rough measure of the degree to which they are achieving their preferred trade-off/choice between work and leisure. Here we classify individuals whose actual working time is within three hours of their preferred time as having their preferences met ('hours ok'). We treat those who work over three hours more than they want as 'overworked', and those who work over three hours less than they want as 'underworked'. Other hours 'gaps' were tested, but the 3-hour variables showed the highest correlation with life satisfaction.

The social participation index used here combines two correlated items about frequency of 'meeting with friends, relatives or neighbours' and 'helping out friends, relatives or neighbours'. ${ }^{5}$ The response scale has just three points: 'every week', 'every month' and 'seldom or never'. These social participation questions have been asked every year in SOEP.

SOEP also includes an annual question about frequency with which the respondent exercises or participates in active sport (rather than spectating). The 1-4 response scale runs from 'almost never' to 'at least once a week'.

\footnotetext{
${ }^{5}$ The correlations have varied from year to year but are usually around 0.3.
} 


\section{Imputed values for explanatory variables}

It should be noted that values for some explanatory variables, which were not included in every wave of SOEP, have been imputed. In particular, the NEOAC has been asked only once (in 2005), so we need to assume that personality is stable and impute it for all other years for which life satisfaction measures are available. Values/life priorities are also imputed for years in which the relevant questions were not asked. ${ }^{6}$ In cases where individuals did not respond to particular survey questions (item non-response), missing values have been imputed 'automatically', using an option available in the STATA structural equation modelling software (STATA, 2011). It has been shown that, when cases are 'missing at random' (rather than 'completely at random'), results can be seriously biased, unless imputation is undertaken (STATA, 2011). ${ }^{7}$ In any panel survey, what are called 'panel conditioning effects' are a possible source of bias. That is, panel members might tend to change their answers over time - and answer differently from the way non-panel members would answer as a consequence just of being panel members. In SOEP there is some evidence that panel members, in their first few years of responding, tended to report slightly higher life satisfaction scores than when they had been participating for a good many years (Frijters, Haisken-DeNew and Shields, 2004). This could be due to 'social desirability bias'; a desire to look good and appear to be a happy person, which may be stronger in the first few years of responding than in later years. Or it could be due to a 'learning effect'; learning to use the middle points of the 0-10 scale, rather than the extremes and particularly the top end.

\footnotetext{
${ }^{6}$ Mean values are imputed for the nearest two adjacent years in which the questions were asked.

${ }^{7}$ By definition, no bias occurs if cases are missing completely at random (MCAR). However, it is more usual for cases to be missing at random (MAR); that is, missingness can be associated with particular values of variables. For example, it is known that very high and very low income earners are less likely than others to answer income questions. If data are MAR, it appears preferable to impute rather than use the standard computing option of 'listwise deletion', which removes any case missing for any single variable in the model.
} 
To compensate for these possible sources of bias, we constructed a variable which measures the number of years panel members have already responded to survey questions. This variable ('years in panel') is included in all equations in which it is statistically significant and improves model fit.

\section{Moving five-year averages of life satisfaction}

In this paper our interest is in medium and long term associations between parent and child life satisfaction, so it is appropriate to base analysis on medium term periods of life satisfaction. Accordingly, we used five-year moving averages of life satisfaction (1984-88, 1985-89, 1986-90...). Most analyses of panel data are of course based on annual measures, reflecting the time interval at which data are actually collected. But it is already known that annual measures and annual changes in life satisfaction are significantly affected by temporary fluctuations due to life events. The purpose of taking multi-year averages, which have been used in previous work analysing panel data, is to iron out temporary fluctuations (Fujita and Diener, 2005; Headey, Muffels and Wagner, 2010; Headey, Muffels and Wagner, 2012). The procedure is similar to that used by economists, who commonly take multi-year periods of income, in order to assess changes in medium or long term ('permanent') income.

In summary, the dependent (outcome) variables in most analyses in the paper are five-year moving averages of the life satisfaction scores of parents and children. Annual measures are used for independent (explanatory) variables.

Structural equation models with two-way causal links: pooled multi-year data Once some preliminary Pearson correlations have been presented, most results are based on structural equation models which estimate the effects of explanatory variables (personality traits, values and behavioral choices) on parent and 'child' life satisfaction. Some of the models are non-recursive. That 
is, they involve two-way causation; estimation of the effects of parental satisfaction on 'child' satisfaction, and also 'child' satisfaction on parental satisfaction.

Structural equation modelling, rather than regression analysis, is necessary whenever the aim is to estimate a set of equations, rather than a single equation, and especially when two-way causal linkages are involved. ${ }^{8}$ The structural equations in this paper are estimated using maximum likelihood (ML) analysis. ${ }^{9}$ ML coefficients and their associated standard errors can be given the same interpretation as regression coefficients. However, assessing the 'goodness of fit' of structural models is more complicated than for regression models. It is necessary to assess the overall fit between estimates for several equations and the input data for the model (a correlation or variance-covariance matrix). ${ }^{10}$ Several measures of fit are conventionally used. The root mean squared error of approximation (RMSEA) is directly based on comparing differences (residuals) between the actual input matrix with the matrix implied by model estimates. ${ }^{11}$ It has become conventional to regard an RMSEA under 0.05 as satisfactory (Bentler, 1990; Browne and Cudeck, 1993).

A more complicated assessment is provided by the comparative fit index (CFI). This is based on a likelihood ratio (LR) chi-square test and takes account of the

\footnotetext{
${ }^{8}$ Regression analysis is essentially a single equation technique. Regression estimates derived from multiequation systems are likely to be biased, due to correlations between explanatory variables and error terms in some or all equations. A key assumption of OLS regression is that such correlations are zero.

${ }^{9}$ ML estimates are usually consistent and asymptotically normal under the (not very restrictive) assumption of conditional normality (STATA, 2011). Only paths or covariances linking conditioning (i.e. control) variables may not be consistent and asymptotically normal (even then, the main problem lies just with estimates of standard errors). These paths are not usually of substantive interest; substantive interest lies in paths (1) linking exogenous with endogenous variables and (2) between endogenous variables.

${ }^{10}$ From a mathematical standpoint, a model can be viewed as a set of constraints - or a set of restricted paths limiting the possibilities of simply reproducing the input data. Attempts by a researcher to improve his/her model involve modifying these constraints to improve model fit, subject to the theory/hypotheses underlying the model.

${ }^{11}$ The standardized root mean squared residual (SRMR) is also based on comparing coefficients in the input and output matrices. However it is not applicable when missing data have been imputed, as is the case in this article.
} 
contribution of each estimate in the model to overall goodness of fit. The CFI rewards parsimony and penalises models including explanatory variables which account for little variance, even if statistically significant. A CFI above 0.90 used to be regarded as satisfactory, but some recent reviews recommend 0.95 (Joreskog and Sorbom, 1986; Browne and Cudeck, 1993). Our experience suggests that it is fairly easy to achieve a 0.95 fit for small models, but that as models get larger, the 0.90 level may realistically be the best that can be achieved. Of course, results should also be assessed by reference to the variance accounted for in the whole model, which is given by the coefficient of determination (CD). Variance accounted for in key dependent (endogenous) variables - parent and 'child' life satisfaction in this paper - also needs to be assessed.

Models which involve two-way causation raise issues of identification; issues about whether there are there sufficient independent pieces of information (variances and covariances) in the input matrix to enable all free parameters in the model to be estimated. The software packages available for estimating structural equation models include checks for identification, but these checks, while usually adequate, may not be conclusive. The particular two-way causation model used in this paper is closely based on a thoroughly researched model, well known in the sociological literature, on the reciprocal links between the occupational aspirations of young people and their peers/friends (Duncan, Haller and Portes, 1968). This specific model, together with identification issues, will be discussed in more detail in the Results section.

Models involving two-way causation can be highly unstable; that is, small changes in model specification can produce large and non-credible changes in results. In view of this, Bentler and Freeman (1983) developed a test of model stability, which is used here. It is also desirable to use Bentler-Raykov (2000) 
multiple correlation coefficients (rather than $\mathrm{R}^{2}$ ) to assess variance accounted for in endogenous variables linked by two-way causation.

We used the new STATA module for structural equation modelling to generate the results reported here (STATA, Release 12, 2011). This package offers a range of estimators, including maximum likelihood, and includes the tests of goodness of fit described above.

It should be understood that all results in this paper are based on pooled analyses. That is, the structural equation models include multiple waves of panel data, but our analyses are not longitudinal in the sense that we do not directly seek to explain changes in life satisfaction over time. Instead we simply make use of the fact that multiple years of data provide larger sample numbers than would single years, and hence offer greater statistical reliability. ${ }^{12}$

Use of Pearson correlations and structural equations with maximum likelihood estimation assumes that the endogenous variables of main interest (five-year moving averages of life satisfaction) are measured on an interval or ratio scale. Strictly speaking, of course, the $0-10$ scale is ordinal. However, it has become routine in work on life satisfaction to treat the data as interval-level. Andrews and Withey (1976) were the first researchers to show that, substantively, results using interval-level statistics were much the same as those using ordinal statistics. Most researchers since have followed their lead.

\section{RESULTS}

Results are given for links among four sets of variables: personality traits, values, behavioral choices and life satisfaction. In estimating structural equation

\footnotetext{
${ }^{12}$ Sample numbers of 'children' living apart from their parents are barely adequate for longitudinal analysis of changes in life satisfaction. This is particularly the case for dyad analysis and analysis involving two-way causation.
} 
models we make assumptions about causal ordering. Personality traits, being partly genetic are assumed to be causally antecedent to all the other variables. Pro-social, family and material values are then assumed to be antecedent to behavioral choices. Traits, values and choices are then all assumed to be potential causes of life satisfaction.

The structural equation model in Figure 1 is heuristic rather than complete. It highlights the causal relationships of interest, but omits some non-causal links (covariances and correlated error terms) which have to be modelled to achieve an acceptable model fit, but whose inclusion would have unduly cluttered the figure.

\section{INSERT FIGURE 1 HERE}

The central purpose of the paper is to estimate the intergenerational transmission links shown in bold type in Figure 1; that is, links between parent and 'child' personality traits, and parent and 'child' values, behaviors and life satisfaction. A question mark has been placed beside the link running from 'child' to parent life satisfaction. This was not expected to be statistically significant (see hypotheses), but in fact proved to be so. The overall model also includes links (shown in non-bold type) among the four sets of variables for parents and also for 'children'. These intra-generational links were the focus of previous papers (Headey, Muffels and Wagner, 2010, 2012). They just need including here to provide an appropriate causal framework within which to model inter-generational links.

The structural equation models actually estimated in the paper are considerably more complicated than shown in Figure 1. Separate models will be estimated for sons and daughters, so that we can compare the relative influence of fathers 
and mothers on male and female 'children'. Furthermore, each model will include estimates of covariances among exogenous variables, and also among error terms of endogenous variables. ${ }^{13}$ Readers familiar with structural equation modelling will recognise that such inclusions are necessary to achieve satisfactory model fits (Bollen, 1989; Wooldridge, 2010). ${ }^{14}$

Finally, it should be noted that, in principle, estimates for all models are net of a more or less standard set of 'controls'. These controls are: age, age squared, age cubed, partner/marital status ( $1=$ partnered, $0=$ not partnered), poor health ( $1=$ health is poor or very poor, $0=$ health is very good, good or fair), net household income, unemployed ( $1=$ unemployed, $0=$ employed or not in the labour force), East German (1=East German, $0=$ not East German), foreign born $\left(1=\right.$ foreign born, $0=$ born in Germany) and number of years in the SOEP panel. ${ }^{15}$ However, some of these variables were dropped from final runs of specific models if they proved not to be statistically significant and worsened the overall fit of the model.

The reasons for including these variables as 'controls' are straightforward. Age is included because it is known that life satisfaction declines somewhat in middle age. ${ }^{16}$ Poor health, being unemployed and household income are all 'objective' conditions, the effects of which need to be netted out in assessing links between parent and child happiness. Finally, it is usual to include a

\footnotetext{
${ }^{13}$ Specifically, we estimates covariances between (1) the error terms of neuroticism and extroversion (2) the error terms of the 3 measures of values (3) the error terms of the 3 measures of behavioral choices and (4) the error terms of the life satisfaction measures for parents and 'children'.

${ }^{14}$ If they are not included, model fit is always extremely poor, because covariances that are present in the input data are only partially accounted for by the causal (structural) links in the model.

${ }^{15}$ Socio-economic variables relating to parents are included in the equations where a parent measure is the dependent variable. Socio-economic variables for 'children' are included in equations where the dependent variable is a 'child' measure.

${ }^{16}$ It is also common to include variables for age-squared and age-cubed, if one's research involves 'following' respondents into and out of middle age. In our equations only the age variable itself was found to be statistically significant; the reason being that we only 'follow' respondents for a few years after 'children' have left the parental home. In early analyses we also included a variable measuring 'years since left the parental home'. This proved not to be statistically significant and was dropped.
} 
dummy variable for foreign born, because foreign immigrants are known to be on average less happy than German-born people (Frijters, Haisken-DeNew and Shields, 2004; Headey, Muffels and Wagner, 2010, 2012).

\section{Short and medium term correlations between parent and child life satisfaction}

Before presenting structural equation models, it is useful to examine bivariate correlations between the life satisfaction of parents and offspring. Table 1 gives Pearson correlations (five-year moving averages) for four dyads: fathers and sons, fathers and daughters, mothers and sons, and mothers and daughters. Results are given separately for children still living in the parental home and those living independently (most of whom are no longer 'children').

Table 1

Five-Year Correlations Between Parent \& 'Child' Life Satisfaction ${ }^{\text {a }}$

\begin{tabular}{|c|c|c|c|c|}
\hline \multirow{2}{*}{$\begin{array}{c}\text { Where 'child' } \\
\text { lives }\end{array}$} & \multicolumn{2}{|c|}{$\begin{array}{c}\text { Life satisfaction of sons } \\
\text { related to.. }\end{array}$} & \multicolumn{2}{c|}{$\begin{array}{c}\text { Life satisfaction of daughters } \\
\text { related to... }\end{array}$} \\
\cline { 2 - 5 } & $\begin{array}{c}\text { Father life } \\
\text { satisfaction }\end{array}$ & $\begin{array}{c}\text { Mother life } \\
\text { satisfaction }\end{array}$ & $\begin{array}{c}\text { Father life } \\
\text { satisfaction }\end{array}$ & $\begin{array}{c}\text { Mother life } \\
\text { satisfaction }\end{array}$ \\
\hline $\begin{array}{c}\text { Lives in } \\
\text { parental home }\end{array}$ & 0.36 & 0.42 & 0.31 & 0.35 \\
$\begin{array}{c}\text { Lives } \\
\text { independently }\end{array}$ & 0.24 & 0.27 & 0.25 & 0.24 \\
\hline $\mathrm{N}$ & 17327 & 17327 & 15203 & 15203 \\
\hline
\end{tabular}

Source: SOEP 1984-2008. The Ns are (person * years).

a. All correlations are significant at the 0.001 level.

The key evidence in Table 1 confirms our first hypothesis about the strength of links between parent and 'child' life satisfaction, even for children who have moved out of the parental home. All four correlations in the second row of the table are in the 0.24-0.27 range. As expected, correlations are higher still (25$50 \%$ higher) for children still living in the parental home. It may be noted that the five-year correlations reported in Table 1 are in fact about one-third higher than equivalent annual correlations, confirming the value for present purposes of preferring medium term measures. 
These initial results are misleading in some respects. The bivariate correlations appear to suggest that hypothesis 2.1 about the links between mother and child life satisfaction being stronger than father-child links might be false (although three of the four mother-offspring correlations are somewhat higher than the corresponding father-offspring correlations). Later multivariate evidence, based on structural equations, will partly contradict these initial results and lead to a more nuanced interpretation of direct and indirect parental influences on the life satisfaction of sons and daughters.

The rest of the paper is entirely focussed on 'children' who have left the parental home and now live separately, in most cases with their own partners. It seems reasonable to expect that the longer a 'child' has been away from the parental home, the less strong will be the correlation between his/her life satisfaction and parental life satisfaction. In Table 2 respondents are split into three groups: those who left the parental home within the last five years, those who left 5-10 years ago, and those who left more than ten years ago.

Table 2

Five-Year Correlations Between Parent \& Child Life Satisfaction, Depending On Length of Time Since The 'Child' Left The Parental Home ${ }^{\mathrm{a}}$

\begin{tabular}{|c|c|c|c|c|}
\hline \multirow{2}{*}{$\begin{array}{c}\text { Years since } \\
\text { left the } \\
\text { parental home }\end{array}$} & \multicolumn{2}{|c|}{$\begin{array}{c}\text { Life satisfaction of sons } \\
\text { related to... }\end{array}$} & \multicolumn{2}{c|}{$\begin{array}{c}\text { Life satisfaction of daughters } \\
\text { related to... }\end{array}$} \\
\cline { 2 - 5 } & $\begin{array}{c}\text { Father life } \\
\text { satisfaction }\end{array}$ & $\begin{array}{c}\text { Mother life } \\
\text { satisfaction }\end{array}$ & $\begin{array}{c}\text { Father life } \\
\text { satisfaction }\end{array}$ & $\begin{array}{c}\text { Mother life } \\
\text { satisfaction }\end{array}$ \\
\hline $\begin{array}{c}\text { Less than 5 } \\
\text { years }\end{array}$ & 0.29 & 0.29 & 0.26 & 0.27 \\
\hline 5-10 years & 0.18 & 0.24 & 0.27 & 0.18 \\
\hline Over 10 years & 0.18 & 0.24 & 0.20 & 0.21 \\
\hline $\mathrm{N}$ & 5568 & 5568 & 6720 & 6720 \\
\hline
\end{tabular}

Source: SOEP 1984-2008. The Ns are (person * years).

a. All correlations are significant at the 0.001 level. 
Our first hypothesis is further confirmed. There are indeed quite substantial correlations between parent and child life satisfaction, even for 'children' who left the parental home more than ten years ago. It is, however, the case that the correlations are less strong for 'children' who have been living independently for five years or more. But even if we combine a range of factors which might be expected to reduce links between parent and child life satisfaction, the correlations still remain substantial. The correlation between father and son life satisfaction for sons who (1) left the parental home more than ten years ago and (2) are age 30+ and (3) are partnered, and (4) live in another town, state or country from both parents is $0.16(\mathrm{~N}=858) .{ }^{17}$ The equivalent correlation for fathers and daughters is $0.25(\mathrm{~N}=1048)$. The mother-son correlation for sons who left home over ten years ago, are age 30+, partnered and living a substantial distance from their parents is $0.25(\mathrm{~N}=858)$. The equivalent motherdaughter correlation is $0.28(\mathrm{~N}=1048)$.

\section{Links between parent and 'child' life satisfaction remain substantial, net of partly hereditary personality traits}

We now focus on the key hypothesis that links between parent and child life satisfaction remain substantial, net of the effects of the partly hereditary personality traits of neuroticism and extroversion. Our first structural equation models will be discussed in some detail, partly for methodological reasons relating to identification and goodness of fit. These models include all variables shown in Figure 1 (above), except for those relating to values and behavioral choices, whose effects on life satisfaction will be estimated later in the paper.

\footnotetext{
${ }^{17}$ These results are for 2006, when respondents were asked questions about where (how far away) their parents lived.
} 
Figures 2 and 3 differ from each other in one important respect. Figure 2 shows one-way causation between parent and son life satisfaction. It is assumed here, that while parents may affect son life satisfaction, son satisfaction has no effect on that of their parents. The two-way model in Figure 3 allows for two-way causation between parent and son satisfaction, following the lead of Aguche and Trommsdorff (2010), who reported that both links were statistically significant. Also included, for obvious reasons, is a two-way link between the life satisfaction of fathers and mothers; they are, after all, married to each other. The coefficients are metric (not standardized) maximum likelihood coefficients, multiplied by 100 to avoid cluttering up the figures with zeros and decimal points.

\section{INSERT FIGURES $2 \& 3$ HERE}

\section{Identification issues}

The identification of equations in a one-way causation model is never in doubt, but identification in a two-way model is often hard to achieve. The most common approach is to look for instrumental variables (instruments) which are only indirectly linked to the dependent (endogenous) variables implicated in two-way causation. It is often difficult to find instruments which can convincingly be claimed to be linked to only one of a pair of two-way causation variables, and which are strongly enough correlated with these variables to serve as effective instruments (Greene, 2008).

For our two-way model (Figure 3), it is necessary to find instruments to identify either the parent or the son life satisfaction equations. We focussed on the son equation because it is clear that father and mother personality traits and socioeconomic characteristics can serve as effective instruments for these equations. The neuroticism, extroversion, household net income, unemployment and 'bad 
health' of both parents are all significantly correlated with their sons' life satisfaction, at least at the 0.05 level. ${ }^{18}$ Plainly, however, these variables should only be regarded as indirectly linked to son life satisfaction; direct links run from sons' own personality traits and socio-economic characteristics.

It was mentioned above that our two-way model is similar to the one analysed in a famous sociological study of reciprocal peer influences (Duncan, Haller and Portes, 1968). For that model the authors recommend inclusion of a parameter reflecting possible covariance between the error terms (unexplained variance) of the endogenous variables of chief interest. The rationale is that the effects of unobserved (omitted) variables, which covary with the endogenous variables of main interest, will be picked up by this parameter estimate (see also Kessler and Greenberg, 1981). In our model we have included three parameters to estimate covariance between the error terms for the life satisfaction of fathers, mothers and offspring. It transpired that the estimates for these parameters were statistically significant and improved the fit of the model (see Appendix Table A1).

\section{Goodness of fit}

The goodness of fit statistics for the one-way causation model are not entirely satisfactory. The RMSEA is under 0.05 but the CFI is 0.89 , which is slightly less than the minimum desirable level of 0.90. By contrast, the two-way causation model is satisfactory on all measures and so is clearly preferable. It has a lower RMSEA (0.03 versus 0.04$)$ and a much higher CFI (0.96 versus 0.89). Furthermore, the two-way model is stable with all eigenvalues falling within the unit circle (Bentler-Freeman, 1983). In this model substantial variance is accounted for in the life satisfaction of fathers (Bentler-Raykov

\footnotetext{
${ }^{18}$ The Pearson correlations are: father's neuroticism $=-0.15$, fathers' extroversion $=0.03$, fathers' household net income $=0.12$, father unemployed $=-0.08$ and father in 'bad health' $=-0.08$.
} 
$\left.\mathrm{mc}^{2}=0.48\right)$ and mothers $\left(\mathrm{mc}^{2}=0.48 \mathrm{p}<0.001\right)$, as well as sons $\left(\mathrm{mc}^{2}=0.18\right.$ $\mathrm{p}<0.001)$.

Before discussion of the substantive interest of the results, here is a parallel model for parents and adult daughters.

\section{INSERT FIGURE 4 HERE}

There is just a moderate association between the neuroticism and extroversion levels of parents and children, with both parents' traits having about equal effects on their offspring. This is exactly what would be expected, given that the traits are known to be partly genetic (Costa and McCrae, 1991; Lucas, 2008).

These models give a first indication - confirmed in later models - that, net of the effects of personality traits, the life satisfaction of mothers directly affects adult children's satisfaction. However, father life satisfaction has no direct influence (later evidence will show indirect influence). The metric ML coefficient linking mother to son life satisfaction is $0.21(\mathrm{p}<0.001)$, whereas the coefficient for father to son satisfaction is not statistically significant. The parallel link for mothers and daughters is 0.27 ( $\mathrm{p}<0.001)$, while the link for fathers and daughters is again not significant. So the mother-offspring links are moderately strong, while the father-offspring direct links are close to zero.

As reported in previous research, two-way links between the life satisfaction of parents are substantial, with male spouses influencing their wives' satisfaction more than the other way round (Winkelmann, 2004; Schimmack and Lucas, 2010).

The surprising finding here, which was certainly not envisaged in our hypotheses, is that the links from 'child' to parent life satisfaction are stronger 
for three dyads - son to father, daughter to father and son to mother - than the reverse links. It appears that ups and downs in the lives of a typical parent and adult child can cause their levels of life satisfaction to covary long after the 'child' has left the parental home. The happiness of some parents, in Germany at least, appears to depend quite substantially on how their adult children's lives are going.

There is one more piece of evidence which tends to suggest continuing reciprocal effects between parents' life satisfaction and the satisfaction of their adult children. If the covariation depended entirely on heredity, plus influences exerted during the period when children were still in the parental home, rather than also on current circumstances, then one might expect that the life satisfaction of the 'children' now (in year t) would correlate more highly with the satisfaction of their parents some years ago than with their parents' current levels of satisfaction. In general, this appears not to be the case, although the evidence is not the same for sons and daughters. The correlations between the current life satisfaction of daughters and their parents are clearly stronger than correlations with parental satisfaction ten years ago, when the daughters were still in the parental home. ${ }^{19}$ However, the correlations between the current life satisfaction of sons and the current satisfaction of their parents are about the same as the correlations between sons now and parents ten years ago. ${ }^{20}$ So the evidence for sons is ambiguous. Perhaps the best interim conclusion is that it is clear that the life satisfaction of daughters continues to affect their fathers' satisfaction (see Figure 4), and that the satisfaction of sons probably continues to influence the satisfaction of their mothers (Figure 3). However, only the

\footnotetext{
${ }^{19}$ The correlation between daughter and father life satisfaction now (for daughters who left home more than five years ago) is 0.24 , whereas the correlation between daughter life satisfaction now and father satisfaction ten years ago is 0.13 . The parallel correlations for daughters and mothers are, respectively, 0.24 and 0.15. Differences between both these pairs of correlations are significant at the 0.001 level.

${ }^{20}$ The correlation between son and father life satisfaction now is 0.15 , compared with 0.16 for son now and father ten years ago. The parallel correlations for sons and mothers are 0.22 and 0.20 . Differences between these pairs of correlations are not significant even at the 0.05 level.
} 
satisfaction of mothers - but not fathers - continues to directly affect adult children.

\section{Inter-generational transmission of values and behavioral choices associated} with life satisfaction

We have found that links between the life satisfaction of parents and adult children are only partly due to inherited personality traits. Here we investigate the hypotheses that the links could also be due to transmission of values (or life priorities) and behaviors known to be associated with happiness.

We now estimate full structural equation models as shown in Figure 1. Results for sons are reported in Figure 5, and for daughters in Figure 6. The full models involve estimation of several hundred variances and covariances. It makes sense here only to give results for the inter-generational links of main interest. ${ }^{21}$ The significant effects of a person's own values and behavioral choices on life satisfaction have been the subject of previous papers and do not need repeating (Headey, Muffels and Wagner, 2010, 2012). Other estimates not reported here are for covariances among exogenous variables (including 'control' variables), and among the error terms of endogenous variables. These estimates are necessary parts of the complete model, but are not of substantive interest. ${ }^{22}$

Finally, before discussing substantive results, we note that measures of fit for these large models are satisfactory. The RMSEAs for both models are 0.03 and the CFIs are both 0.91 . Both satisfy the Bentler-Freeman stability criterion for two-way causation models. Substantial variance is accounted for in the life

\footnotetext{
${ }^{21}$ Results for the full model are available as computer print-out from the authors.

${ }^{22}$ In the final models (Figures 5 and 6) parent traits, values and behaviors (but not life satisfaction) were treated as correlated exogenous variables, rather than as endogenous. This could be done without losing estimates of substantive interest, and had the benefit of improving the fit of final models.
} 
satisfaction of parents, sons and daughters. The coefficient of determination for the sons' model is 0.81 and for the daughters' model it is 0.80 .

\section{INSERT FIGURES 5 AND 6 HERE}

\section{Transmission of values}

Sons appear to get pro-social, altruistic values primarily from their fathers $(b=0.06 p<0.001)$ and not at all from their mothers $(b=0.02 p>0.05)$. Daughters, on the other hand, get altruistic values about equally from both parents (father $b=0.06 p<0.001$ mother $b=0.08 p<0.001)$. Interestingly, and presumably due to modelling in the home, both sons and daughters get their family values only from their mothers. For sons the link to mothers' family values is 0.15 $(p<0.001)$ and for daughters it is $0.12(p<0.001)$. Links with fathers' family values are not statistically significant. Transmission of material (or materialistic) values comes from both parents, although the results for daughters suggest that the influence of mothers is stronger than fathers.

\section{Transmission of behavioral choices}

Although the possibility was envisaged in our hypotheses, it was somewhat surprising to find that parents can effectively model 'work-life balance'. It seemed likely that changes in the workforce in recent decades - particularly the gender balance - would make it improbable that sons and daughters would be much affected in practice by the preferences of their parents, even if they happened to share those preferences. However, parents who report working approximately the hours they prefer turn out to have sons and daughters who also manage to achieve their preferred work-leisure trade-off. Similarly, there are positive correlations between parental and adult 'child' reports of being 'overworked', 'underworked', unemployed, and not in the labor force.

The work-life balance of sons appears to be modelled on the experience of their 
fathers rather than their mothers. The ML coefficient linking fathers' and sons' achievement of a preferred work-life balance (labelled 'hours ok' in Figure 5) is 0.05 ( $\mathrm{p}<0.001)$. Daughters appear to be about equally influenced by their fathers $(b=0.04 p<0.001)$ and mothers $(b=0.03 p<0.05)$.

Both parents appear to have about equal influence on the social participation and exercise habits of their sons and daughters. All ML coefficients in Figures 5 and 6, reporting these inter-generational links, are positive and all are statistically significant at the 0.001 level.

In summary, it is clear that parents transmit happiness-related values and behaviors to their children with effects lasting into adulthood. It might have been thought that transmission of values would be stronger than transmission of specific behaviors, but this does not appear to be the case. In general, the influence of both parents seems to be about equally strong. However, mothers have more influence than fathers on the family values of both sons and daughters. Fathers have more influence on the development of sons' pro-social values and work-life balance, and mothers have more influence on their daughters' material values.

\section{Inter-generational transmission of life satisfaction}

Finally, we consider the two-way links between parent and 'child' life satisfaction. It should be borne in mind (see Figure 1) that estimates for these links are net of the personality traits, values and behavioral choices of the individuals involved. So, for example, the ML coefficients linking mother and daughter life satisfaction are net of the traits, values and choices of mothers and daughters.

Another statistical point to keep in mind is that Figures 5 and 6 only show direct 
effects - direct links between variables. The total effects of antecedent variables on endogenous variables are also calculable (and are routinely provided by structural equation programs) and can be crucial to understanding relationships among variables of interest. Total effects are equal to direct effects plus the sum of indirect effects (Bollen, 1989; Wooldridge, 2010). In presenting results relating to transmission of traits, values and behavioral choices, we considered only direct effects. This was because direct and total effects are identical (or almost identical) in these segments of the overall model. However, when we consider transmission of life satisfaction, it turns out that evidence about total effects changes and expands the understanding gained from looking just at direct effects.

The life satisfaction of both sons and daughters is directly influenced only by mothers and not at all by fathers. The direct link between mother and son life satisfaction is $0.14(p<0.001)$, and the link between mother and daughter life satisfaction is $0.29(\mathrm{p}<0.001)$. The direct influence of fathers is not statistically significant. However, it would be mistaken to jump to the conclusion that fathers do not affect the life satisfaction of their adult children at all. We have already seen that they affect the children's traits, values and behavioral choices. They also strongly influence the life satisfaction of mothers. So it is possible, and indeed proves to be the case, that their total effect on children's happiness is significant. The total effect of father life satisfaction on son life satisfaction is 0.11 (direct effect $=0.03$ indirect effect $=0.08$ ), and the total effect of father life satisfaction on daughter life satisfaction is 0.08 (direct effect $=-0.05$ indirect effect $=0.14){ }^{23}$ The total and indirect effects are statistically significant at the 0.001 level, even though the direct effects are non-significant.

Of course mothers indirectly influence the happiness of their offspring too.

\footnotetext{
${ }^{23}$ The total effect appears not to exactly equal the sum of direct and indirect effects only due to rounding.
} 
The estimated total effect of mothers on the life satisfaction of their sons is 0.19 (direct effect $=0.14$ indirect effect $=0.04)$, and on their daughters 0.31 (direct effect 0.29 indirect effect 0.03$){ }^{24}$

So mothers clearly have greater influence than fathers on the happiness of adult sons and daughters. It was hypothesized that it might nevertheless be the case that fathers have relatively more influence on sons. Earlier evidence suggested that they do quite strongly influence sons' values and behaviors. However, the difference between the total effect of father life satisfaction on son life satisfaction $(b=0.11 \mathrm{p}<0.001)$, compared to daughter life satisfaction $(b=0.08$ $\mathrm{p}<0.001)$ is not statistically significant even at the 0.05 level.

The most puzzling results shown in Figures 5 and 6 concern the effects of adult children's life satisfaction on their parents' satisfaction, which appear to be as strong or stronger than parent-to-child links. These results were not envisaged in our initial hypotheses. Possible explanations are canvassed in the Discussion section.

\section{DISCUSSION}

Our central finding is that parents transmit life satisfaction or dissatisfaction to their children. This transmission occurs partly due to transmission of values and behavioral choices associated with satisfaction. Giving high priority to prosocial and family values, rather than material values, promotes happiness. So, also, do implementing a preferred work-leisure balance, active social participation and regular exercise. A practical implication is that parents who themselves have pro-happiness values and behaviors should explicitly articulate and inculcate them, rather than just rely on quiet modelling.

\footnotetext{
${ }^{24}$ The total effect appears not to equal the sum of direct and indirect effects only due to rounding.
} 
Plainly, the particular values and choices we have identified do not by any means account for all the covariance between parent and 'child' life satisfaction. It seems certain that other values and behavioral choices must be implicated. Various beliefs, skills and capabilities - for example, religious beliefs, 'emotional intelligence' and a capacity for intimate attachment - are likely to be involved.

On the basis of the psychological literature on childhood emotional development, it was hypothesized that mothers would have more influence on adult children's life satisfaction than fathers, and this appears to be the case. Our final models (Figures 5 and 6), plus calculations of total effects, show that the life satisfaction of mothers substantially affects the life satisfaction of both adult sons and adult daughters. The direct effects of father life satisfaction are not statistically significant, but fathers do have significant indirect effects via their personality traits, values and behaviors, and also their influence on the happiness of mothers.

It is worth recalling that this article has been about 'intact' families; families in which marital separation did not occur prior to children leaving the parental home. It is likely, although not certain, that the influence of fathers would be less in 'broken' families, especially if (as is usually the case) the children were raised mainly by their mothers after marital separation.

The most unexpected finding of the paper is that the life satisfaction of adult children continues to have quite strong effects on the satisfaction of their parents. The effect of sons on their mothers' life satisfaction is particularly strong. It is interesting to speculate why our findings run somewhat counter to those of Aguche and Trommsdorff (2010), who found that links from parent to-child happiness were much stronger than the reverse links. Aguche and 
Trommsdorff's research dealt with parents and children living in the same home. It may be that, when the 'children' move out, relationships change...the 'children' now have busy lives and are not as strongly affected by their parents' happiness (or other parental influences) as they were before. The parents, on the other hand, may have less busy lives, and their life satisfaction may still be much affected by how their children are doing. Of course, circumstances vary from family to family. The results here - the maximum likelihood estimates are just averages, and it is likely that in some families parent to adult child life satisfaction linkages remain very strong.

These issues of two-way causation are certainly worth further investigation. Ideally, the focus should be on year-to-year (longitudinal) covariations in parent and child satisfaction. At present, the sample numbers of adult children available in the German panel for estimation of genuinely longitudinal two-way causation models (recall that the analysis here has used pooled data) are quite limited. However, the numbers of parents and adult children in the dataset are increasing every year, so this type of analysis will soon become feasible.

In this article we have focussed on transmission of life satisfaction from one generation to the next. But the 'real' picture is more complicated. Assortative mating is involved. Men and women with pro-happiness traits (low on neuroticism, high on extroversion) tend to partner/marry each other. Then they have children with pro-happiness traits. These children grow up and in turn find their own partners with pro-happiness traits. Together they too have relatively happy children. The strength of association between the life satisfaction of successive generations is bound to get weaker over time, the more generations are involved... for obvious reasons of increasing genetic and environmental diversity. However, if we focus on individuals in the middle generation of the scenario sketched above, it can be inferred that their life satisfaction depends on 
a complicated network of two-way causation. Their life satisfaction is partly due to personality traits inherited from their parents, partly due to parental modelling, partly due to having happy or unhappy partners (a two-way effect), and partly due to having happy or unhappy children (also a two-way effect).

In future research it will be important to try and take account of two-way causation of happiness within and between generations of the same families. The German panel data, and other household panel datasets becoming available, will eventually make it possible to trace links across three generations. In later work it will also be important to look into inter-generational happiness mobility, rather than just studying stability (or transmission). Why are some children happier than their parents and others less happy? 


\section{APPENDIX}

Full results for all models in the paper are available from the authors. The model below, which underlies Figure 3 in the text, is printed to assist understanding and comment on the structural equation models with 2-way causation, which form the core of the paper. This model includes 2-way causal links between father and son life satisfaction, mother and son life satisfaction, and father and mother life satisfaction. Also included are estimates of the covariances of four pairs of error terms: son neuroticism and son extroversion, father and son life satisfaction, mother and son life satisfaction, and mother and son life satisfaction.

Table A1 (see Figure 3 in main text): Relationships Between Father, Mother \& Son Life Satisfaction, Net Of Personality Traits \& Socio-Economic Characteristics: pooled ML estimates (metric coefficients with standard errors in parentheses) ${ }^{\mathrm{a}}$

\begin{tabular}{|c|c|c|c|c|c|}
\hline & $\begin{array}{c}\text { Son } \\
\text { Neuroticism } \\
\end{array}$ & Son Extroversion & $\begin{array}{l}\text { Father Life } \\
\text { Satisfaction }\end{array}$ & $\begin{array}{l}\text { Mother Life } \\
\text { Satisfaction }\end{array}$ & $\begin{array}{c}\text { Son Life } \\
\text { Satisfaction }\end{array}$ \\
\hline $\begin{array}{c}\text { Father } \\
\text { Neuroticism }\end{array}$ & $\begin{array}{c}0.12 * * * \\
(0.01)\end{array}$ & & $\begin{array}{c}-0.20 * * * \\
(0.01)\end{array}$ & & \\
\hline $\begin{array}{c}\text { Mother } \\
\text { Neuroticism }\end{array}$ & $\begin{array}{c}0.10^{* * * *} \\
(0.01)\end{array}$ & & & $\begin{array}{c}-0.20 * * * \\
(0.01)\end{array}$ & \\
\hline $\begin{array}{c}\text { Father } \\
\text { Extroversion }\end{array}$ & & $\begin{array}{c}0.08 * * * \\
(0.01)\end{array}$ & $\begin{array}{c}0.14 * * * \\
(0.01)\end{array}$ & & \\
\hline $\begin{array}{c}\text { Mother } \\
\text { Extroversion }\end{array}$ & & $\begin{array}{c}0.07 * * * \\
(0.01)\end{array}$ & & $\begin{array}{c}0.04 * * * \\
(0.01)\end{array}$ & \\
\hline $\begin{array}{l}\text { Father Life } \\
\text { Satisfaction }\end{array}$ & & & & $\begin{array}{c}0.43 * * * \\
(0.02)\end{array}$ & $\begin{array}{l}-0.01 \\
(0.03)\end{array}$ \\
\hline $\begin{array}{l}\text { Mother Life } \\
\text { Satisfaction }\end{array}$ & & & $\begin{array}{c}0.30 * * * \\
(0.02)\end{array}$ & & $\begin{array}{c}0.16 * * * \\
(0.03)\end{array}$ \\
\hline $\begin{array}{c}\text { Son } \\
\text { Neuroticism }\end{array}$ & & & & & $\begin{array}{c}-0.15 * * * \\
(0.01)\end{array}$ \\
\hline $\begin{array}{c}\text { Son } \\
\text { Extroversion }\end{array}$ & & & & & $\begin{array}{c}0.10^{* * * *} \\
(0.01)\end{array}$ \\
\hline $\begin{array}{c}\text { Son Life } \\
\text { Satisfaction }\end{array}$ & & & $\begin{array}{c}0.11 * * * \\
(0.03)\end{array}$ & $\begin{array}{c}0.21 * * * \\
(0.03)\end{array}$ & \\
\hline Age $^{b}$ & $\begin{array}{c}0.01 * * * \\
(0.00)\end{array}$ & $\begin{array}{c}-0.03 * * * \\
(0.00) \\
\end{array}$ & $\begin{array}{c}0.01 * * * \\
(0.00)\end{array}$ & $\begin{array}{c}0.01 * * * \\
(0.00)\end{array}$ & $\begin{array}{c}-0.03 * * * \\
(0.00)\end{array}$ \\
\hline Partnered $(1 / 0)$ & $\begin{array}{c}0.14 * * * \\
(0.03)\end{array}$ & & & $\begin{array}{c}0.78 * * * \\
(0.05) \\
\end{array}$ & \\
\hline HH Net Income & $\begin{array}{c}-0.07 * * * \\
(0.01)\end{array}$ & & $\begin{array}{c}0.06^{* * * *} \\
(0.01)\end{array}$ & & $\begin{array}{c}0.15 * * * \\
(0.01)\end{array}$ \\
\hline $\begin{array}{l}\text { Unemployed } \\
(1 / 0)\end{array}$ & $\begin{array}{l}0.25 * * * \\
(0.06)\end{array}$ & & $\begin{array}{c}-0.45 * * * \\
(0.04)\end{array}$ & $\begin{array}{c}-0.33 * * * \\
(0.05)\end{array}$ & $\begin{array}{c}-0.88 * * * \\
(0.06)\end{array}$ \\
\hline Bad Health (1/0) & $\begin{array}{c}0.67 * * * \\
(0.06)\end{array}$ & & $\begin{array}{c}-0.99 * * * \\
(0.03)\end{array}$ & $\begin{array}{c}-0.87 * * * \\
(0.03) \\
\end{array}$ & $\begin{array}{c}-1.10 * * * \\
(0.06)\end{array}$ \\
\hline $\begin{array}{c}\text { Foreign Born } \\
(1 / 0) \\
\end{array}$ & $\begin{array}{l}-0.07 \\
(0.04) \\
\end{array}$ & $\begin{array}{c}0.17 * * * \\
(0.04)\end{array}$ & & & \\
\hline Years In Panel & $\begin{array}{c}-0.01 * * \\
(0.00)\end{array}$ & $\begin{array}{c}0.02 * * * \\
(0.00)\end{array}$ & $\begin{array}{c}-0.02 * * * \\
(0.00)\end{array}$ & $\begin{array}{c}-0.01 * * \\
(0.00)\end{array}$ & \\
\hline $\begin{array}{c}\text { Bentler-Raykov } \\
\mathrm{mc}^{2}\end{array}$ & 0.07 & 0.04 & 0.48 & 0.48 & 0.18 \\
\hline $\mathrm{N}$ & 9626 & 9626 & 9626 & 9626 & 9626 \\
\hline
\end{tabular}

a. Coefficients for covariances of error terms: son neuroticism and son extroversion $-0.08(\mathrm{p}=0.01)^{* * *}$, father and mother life satisfaction $-0.17(\mathrm{p}=0.04)^{* * *}$, father and son life satisfaction $-0.02(\mathrm{p}=05)^{* * *}$, mother and son life satisfaction $-0.38(\mathrm{p}=0.05)^{* * *}$. Covariances linking exogenous variables, and also error terms of endogenous variables (variance not accounted for) are not printed.

b. Measures of age and all remaining explanatory variables (listed below) relate to the individual (father or mother or son) to whom the endogenous (outcome) variable relates.

$* * *$ significant at $0.001 * *$ significant at $0.01 *$ significant at 0.05

Additional measures of fit: LR test $\mathrm{chi}^{2}(75)=604.81 \mathrm{p}<0.001 ; \mathrm{RMSEA}=0.03 ; \mathrm{CFI}=0.96 ; \mathrm{CD}=0.66$; BentlerFreeman test of model stability $=0.42$ (all eigenvalues within unit circle). 


\section{REFERENCES}

Aguche, A. and Trommsdorff, G (2010) Transmission of well-being between mothers, fathers and adolescent children: the role of parenting and personality factors, $9^{\text {th }}$ International German Socio-Economic Panel User Conference, June 30-July 1.

Andrews, F.M. and Withey, S.B. (1976) Social Indicators Of Well-Being. New York, Plenum.

Argyle, M. (2001, $2^{\text {nd }}$ edition) The Psychology Of Happiness. London, Taylor and Francis.

Bentler, P.M. (1990) Comparative fit indices in structural models, Psychological Bulletin, 107, 238-46.

Bentler, P.M. and Freeman, E.H. (1983) Tests for stability in linear structural equation systems, Psychometrika, 143-45.

Bentler, P.M. and Raykov, T. (2000) On measures of explained variance in nonrecursive structural equation models, Journal of Applied Psychology, 85, 12531.

Bollen, K.A. (1989) Structural Equations With Latent Variables, New York, Wiley.

Bookwala, J. and Schulz, R. (1996) Spousal similarity in subjective well-being: the cardiovascular health study, Psychology and Aging, 11, 582-90.

Bourgeois, M. and Friedkin, N.E. (2001) The distant core: social solidarity, social distance and interpersonal ties in core-periphery structures, Social Networks, 23, 245-60.

Bowlby, J. (1988) A Secure Base: Clinical Applications Of Attachment Theory. London, Routledge.

Bradburn, N.M. (1969) The Structure of Psychological Well-Being. Chicago, Aldine.

Browne, M.W. and Cudeck, R. (1993) 'Alternative ways of assessing model fit' in K.A. Bollen and J.S. Long eds. Testing Structural Equation Models.

Newbury Park, Ca., Sage. 
Campbell, A., Converse, P.E. and Rodgers, W.R. (1976) The Quality of American Life. New York, Sage.

Clark, A.E., Georgellis, Y., Lucas, R.E. and Diener, E. (2004) Unemployment alters the set point for life satisfaction, Psychological Science, 15, 8-13. Clark, A.E., Diener, E., Georgellis, Y. and Lucas, R.E. (2008) Lags and leads in life satisfaction: A test of the baseline hypothesis, Economic Journal, 118, 22243.

Costa, P.T. and McCrae, R.R. (1980) Influences of extroversion and neuroticism on subjective well-being, Journal of Personality and Social Psychology, 38, 668-78.

Costa, P.T. and McCrae, R.R. (1991) The NEO PI-R. Odessa, Fl., PAR.

Diener, E., Suh, E.M., Lucas, R.E. \& Smith, H.L. (1999) Subjective well-being: Three decades of progress, Psychological Bulletin, 25, 276-302.

Diener, E. and Biswas-Diener, R. (2008) Happiness: Unlocking The Mysteries Of Psychological Wealth. Oxford, Blackwell.

Diener, E. and Seligman, M.E.P. (2004) Beyond money: Toward an economy of well-being, Psychological Science in the Public Interest, 5, 1-31.

Duncan, O.D., Haller, A.O. and Portes, A. (1968) Peer influences on aspirations: A reinterpretation, American Journal of Sociology, 74, 119-37.

Dunn, E.W., Aknin, L.B. and Norton, M.I. (2008) Spending money on others promotes happiness, Science, 319, 1687-88.

Emmons, R.A. (1986) Personal strivings: An approach to personality and subjective well-being, Journal of Personality and Social Psychology, 51, 105868.

Frijters, P., Haisken-DeNew, J.P. and Shields, M.A. (2004) Money Does Matter! Evidence from Increasing Real Incomes and Life Satisfaction in East Germany Following Reunification, American Economic Review, 94, 730-41.

Fujita, F. and Diener (2005) Life satisfaction set-point: Stability and change. Journal of Personality and Social Psycholgy, 88, 158-64.

Gerlitz, J.-Y. and Schupp, J. (2005) Zur Erhebung der Big-Five-basierten Persoenlichkeitsmerkmale im SOEP. 
Gottman, J. and Declaire, J. (1998) Raising An Emotionally Intelligent Child. New York, Simon and Schuster.

Greene, W.H. (2008) Econometric Analysis ( $7^{\text {th }}$ edition). New York, Prentice Hall.

Guven, C., Senik, C. and Stichnoth, H. (2010) You can't be happier than your wife: happiness gaps and divorce, SOEP Paper 261.

Harlow, R.E. and Cantor, N. (1996) Still participating after all these years: A study of life task participation in later life, Journal of Personality and Social Psychology, 71, 1235-49.

Headey, B. (1987) The Subjective Well-Being and Ill-Being of Families, in D. Tait ed. Family Well-Being. Melbourne, Australian Institute of Family Studies, pp. 14-18.

Headey, B.W., Warren, D. and Harding, G. (2005) Changes in marital status 2001-2003; and satisfaction levels just before separation in Families, Incomes and Jobs: A Statistical Report Of The HILDA Survey. Melbourne, Melbourne Institute of Applied Economic and Social Research.

Headey, B.W. (2008) Life goals matter to happiness: A revision of set-point theory, Social Indicators Research, 86, 213-31.

Headey, B.W., Muffels, R.J.A. and Wagner, G.G. (2010) Long-running German panel survey shows that personal and economic choices, not just genes, matter for happiness, Proceedings of the National Academy of Sciences, 107.42, 17922-17926 (Oct. 19).

Headey, B.W., Muffels, R.J.A. and Wagner, G.G. (2012) Choices which change life satisfaction: Similar results for Australia, Britain and Germany, Social Indicators Research (24 May) 1-24. Published online DOI 10.1007/s11205-0120079-8.

Joreskog, K.G and Sorbom, D. (1986) LISREL VI: Analysis of Linear Structural Relationships by the Method of Maximum Likelihood. Mooresville, Ind., Scientific Software.

Kasser, T. and Kanner, A.D. eds. (2004) Psychology and Consumer Culture: The Struggle for the Good Life in a Materialistic World. Washington D.C., American Psychological Association. 
Kessler, R.C. and Greenberg, D.F. (1981) Linear Panel Analysis. New York, Academic Press.

Kind, M. and Haisken-DeNew, J.P. (2010) Unexpected victims - how parents' unemployment affects their children's life satisfaction, $9^{\text {th }}$ International German Socio-Economic Panel User Conference.

Kluckhohn, F.R. and Strodtbeck, F.L. (1961) Variations in Value Orientations. Evanston, Illinois, Row, Peterson.

Little, I.M.D. (2002 edition) A Critque Of Welfare Economics. Oxford, Oxford University Press.

Lucas, R.E. (2008) Personality and subjective well-being in M. Eid and R.J. Larsen eds. The Science of Subjective Well-Being. New York, Guilford Press, pp. 171-94.

Lyubomirsky, S. (2008) The How of Happiness: A Scientific Approach to Getting the Life You Want. New York, Penguin.

Nickerson, C., Schwarz, N., Diener, E. and Kahneman, D. (2003) Zeroing in on the dark side of the American dream: A closer look at the negative consequences of the goal for financial success, Psychological Science, 14, 53136.

Ostwald, S.K., Godwin, K.M. and Cron, S.G. (2009) Predictors of life satisfaction in stroke survivors and their caregivers after inpatient rehabilitation, Rehabilitation Nursing, 34, 160-74.

Powdthavee, N. (2008) I can't smile without you: spousal correlation in life satisfaction, York University, Department of Economics, Discussion Paper 08/16.

Putnam, R.D. (2000) Bowling Alone: The Collapse and Revival of American Community. New York, Simon \& Schuster.

Roberts, B.W., Walton, K. and Viechtbauer, W. (2006) Patterns of mean-level change in personality traits across the life course: A meta-analysis of longitudinal studies, Psychological Bulletin, 132, 3-27.

Schimmack, U. and Lucas, R.E. (2010) Environmental influences on wellbeing: a dyadic latent panel analysis of spousal similarity, Social Indicators Research, 98, 1-21. 
Scollon, C.N. and Diener, E. (2006) Love, work and changes in extroversion and neuroticism over time, Journal of Personality and Social Psychology, 91, 1152-65.

STATA (2011) Structural Equation Modeling Reference Manual. College Station, Texas, Stata Press.

Thoits, P.A. and Hewitt, L.N. (2001) Volunteer work and well-being, Journal of Health and Social Behavior, 42, 115-31.

Wagner, G.G., Frick, J. R., and Schupp, J. (2007) The German Socio-Economic Panel Study (SOEP) - Scope, Evolution and Enhancements, Schmoellers Jahrbuch 127 (1), 139-69.

Winkelmann, L. and Winkelmann, R. (1995) Happiness and unemployment: a panel data analysis for Germany, Konjuncturpolitik, 41, 283-307.

Winkelmann, R. (2004) Subjective well-being and the family: results from an ordered probit model with multiple random effects, IZA DP No. 1016.

Wooldridge, J.M. (2010) Econometric Analysis Of Cross-Section And Panel Data. $\quad 2^{\text {nd }} \quad$ ed. $\quad$ Cambridge, Mass., $\quad$ MIT Press. 
Figure 1: Parental Transmission of Personality Traits, Values, Behavioral Choices and Life Satisfaction to Sons and Daughters

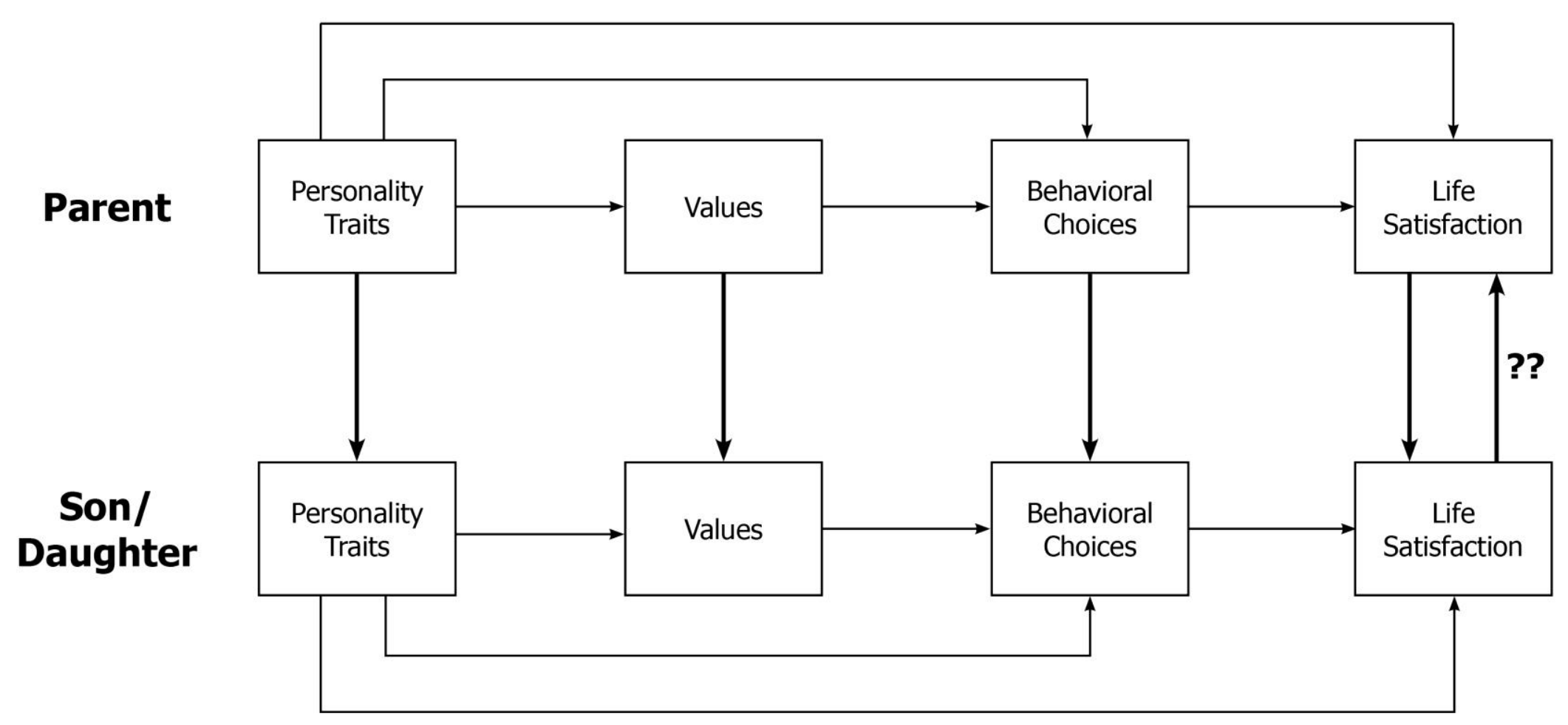




\section{Figure 2}

Effects of Parental Life Satisfaction On Son Life Satisfaction, Net Of Personality Traits: One-Way Causation ${ }^{\text {abc }}$

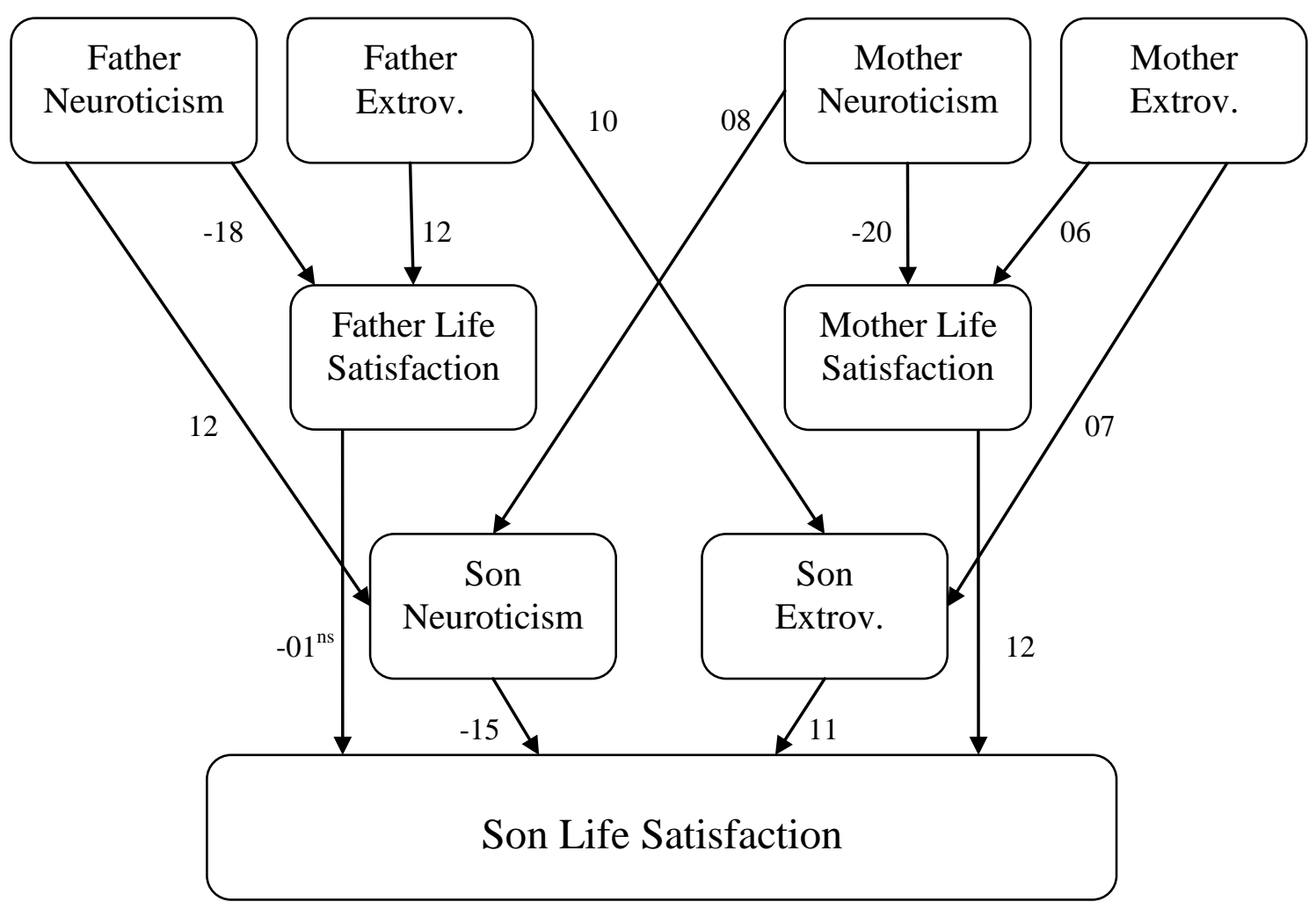

a. Pooled ML estimates $=$ metric coefficients*100. Initially, results were obtained net of age, partner status (10 ), net annual household income, unemployed (1-0), ill-health (1-0), foreign born and years in the panel. Variables not statistically significant at 0.05 , and which detracted from the fit, were dropped from final models. b. Coefficients are significant at the 0.001 level unless marked ns=not significant, or $*=$ significant at 0.05 . c. The model also includes estimates of the covariances of the three error terms for father, mother and son life satisfaction, plus the covariance of the error terms for neuroticism and extroversion.

Measures of fit and variance accounted for: one-way causation model LR test chi $^{2}$ (79) $=1494.86$ p $<0.001 ;$ RMSEA=0.04; CFI=0.89; $\mathrm{CD}=0.47 ; \mathrm{R}^{2}$ for fathers' life satisfaction $=0.16 ; \mathrm{R}^{2}$ for mothers' life satisfaction $=0.14 ; \mathrm{R}^{2}$ for sons' life satisfaction $=0.07$. Sample N=9626. 
Figure 3

Two-Way Effects of Parental Life Satisfaction On Son Life Satisfaction and Vice-Versa, Net Of Personality Traits ${ }^{\text {abc }}$

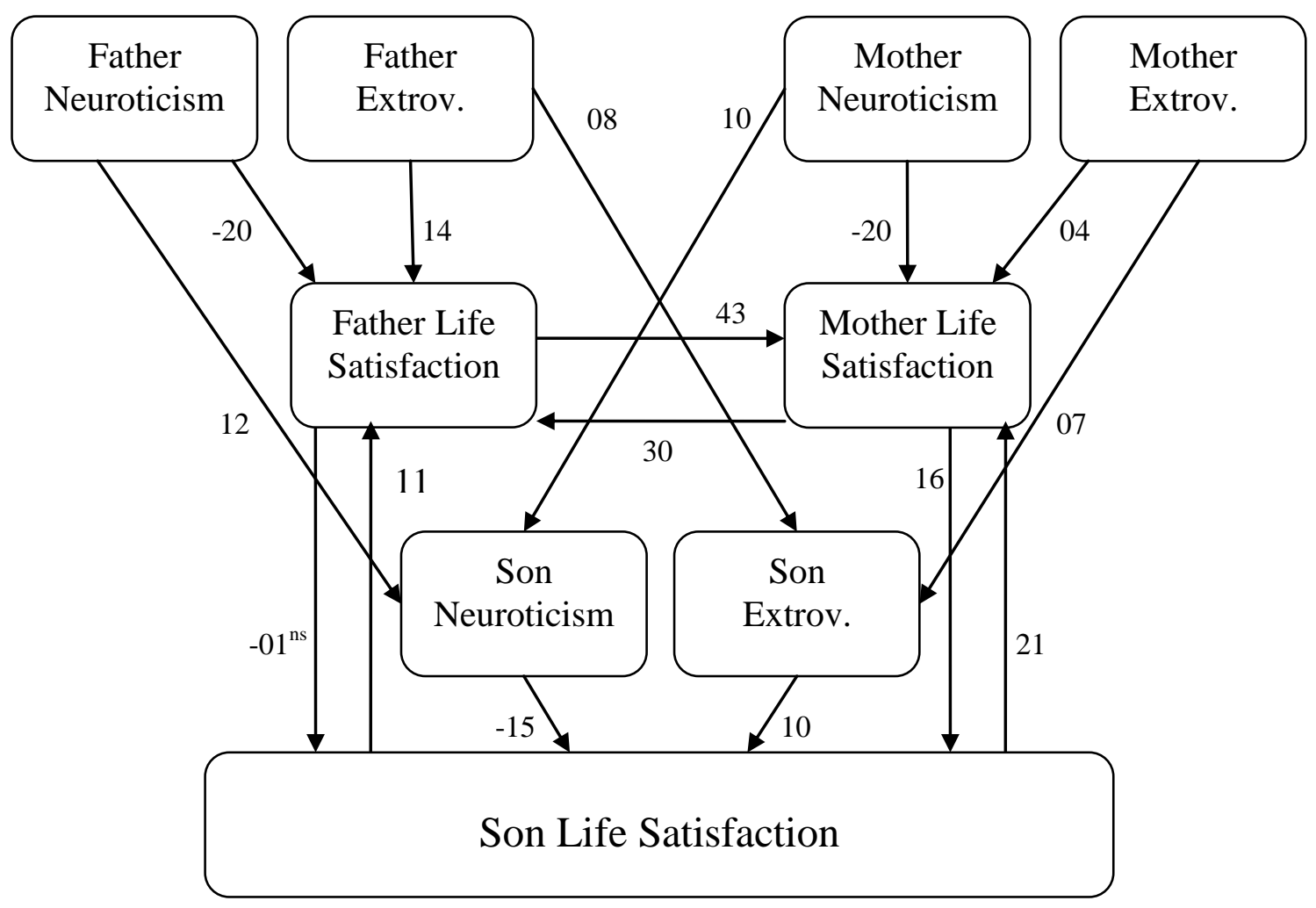

a. Pooled ML estimates $=$ metric coefficients*100. Initially, results were obtained net of age, partner status (10 ), net annual household income, unemployed (1-0), ill-health (1-0), foreign born and years in the panel.

Variables not statistically significant at 0.05 , and which detracted from the fit, were dropped from final models.

b. Coefficients are significant at the 0.001 level unless marked ns=not significant, or $*=$ significant at 0.05 .

c. The model also includes estimates of the covariances of the three error terms for father, mother and son life satisfaction, plus the covariance of the error terms for neuroticism and extroversion.

Measures of fit and variance accounted for: two-way causation model LR test $\mathrm{chi}^{2}(75)=$ 604.81 p $<0.001$; RMSEA=0.03; CFI=0.96; $\mathrm{CD}=0.66$; Bentler-Raykov $\mathrm{mc}^{2}$ for fathers' life satisfaction $=0.48 ; \mathrm{mc}^{2}$ for mothers' life satisfaction $=0.48 ; \mathrm{mc}^{2}$ for sons' life satisfaction $=$ 0.18 ; Bentler-Freeman test of model stability $=0.42$ (all eigenvalues within unit circle).

Sample N=9626. 


\section{Figure 4}

Two-Way Effects of Parental Life Satisfaction On Daughter Life Satisfaction and ViceVersa, Net Of Personality Traits ${ }^{\text {abc }}$

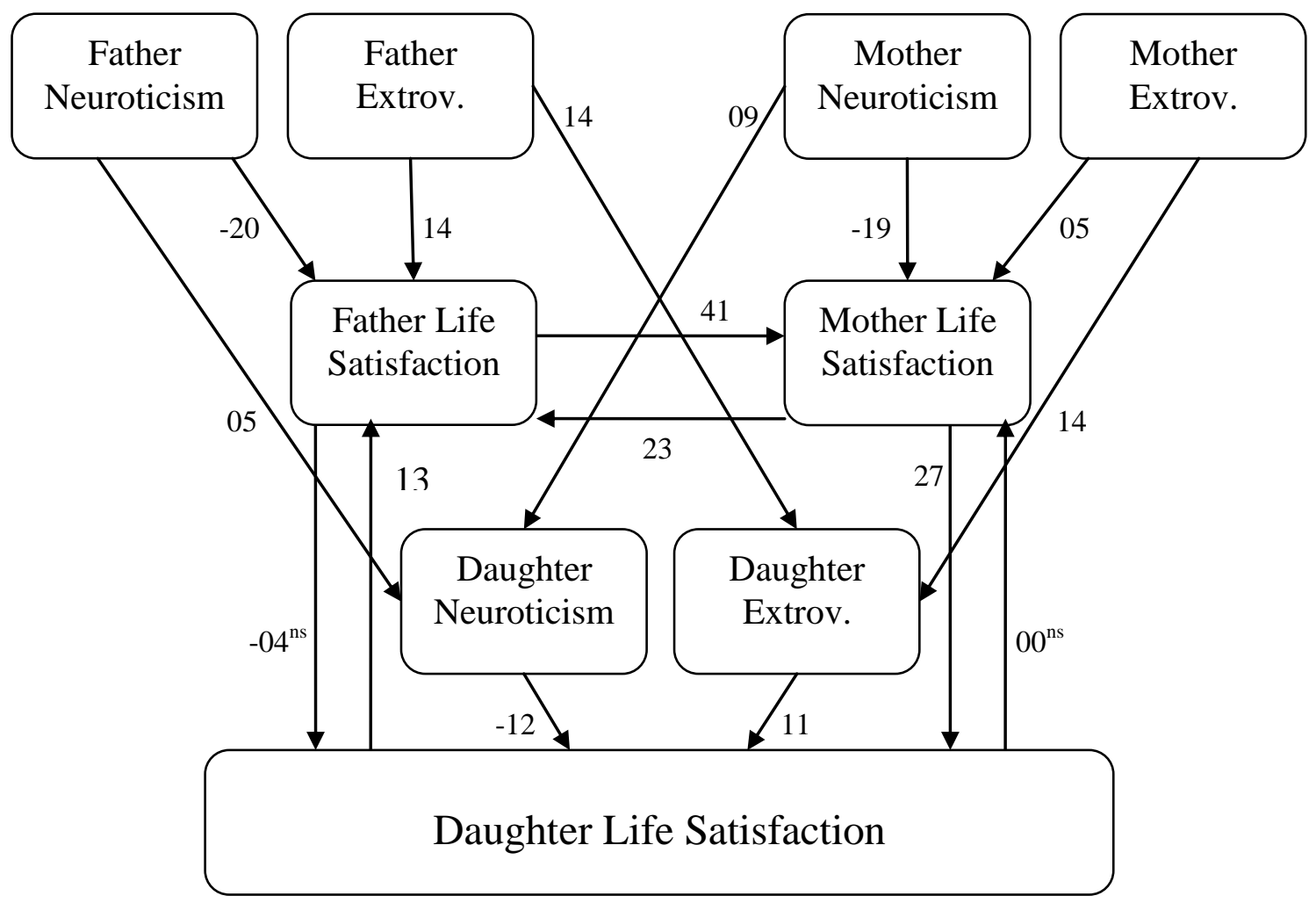

a. Pooled ML estimates = metric coefficients*100. Initially, results were obtained net of age, partner status (10 ), net annual household income, unemployed (1-0), ill-health (1-0), foreign born and years in the panel. Variables not statistically significant at 0.05 , and which detracted from the fit, were dropped from final models. b. Coefficients are significant at the 0.001 level unless marked ns (not significant) or * significant at 0.05 . c. The model also includes estimates of the covariances of the three error terms for father, mother and son life satisfaction, plus the covariance of the error terms for neuroticism and extroversion.

Measures of fit and variance accounted for: two-way causation model LR test $\operatorname{chi}^{2}(75)=$ $651.64 \mathrm{p}<0.001$; RMSEA=0.03; CFI=0.96; $\mathrm{CD}=0.59$; Bentler-Raykov $\mathrm{mc}^{2}$ for fathers' life satisfaction $=0.45 ; \mathrm{mc}^{2}$ for mothers' life satisfaction $=0.45 ; \mathrm{mc}^{2}$ for daughters' life satisfaction $=0.14$; Bentler-Freeman test of model stability $=0.36$ (all eigenvalues within unit circle). Sample N=10440. 
Figure 5: Parental Transmission of Values, Behavioral Choices and Life Satisfaction to Sons (metric ML coefficients: N=9626)

\section{Values}

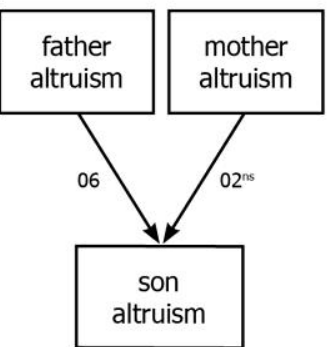

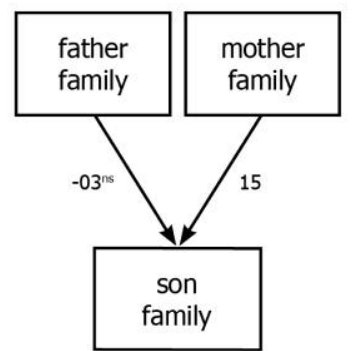

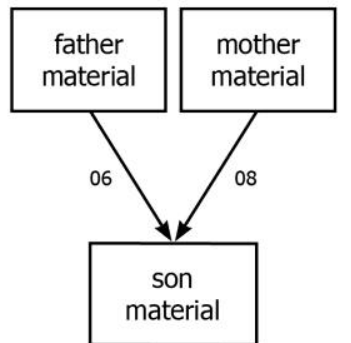

Behavioral Choices

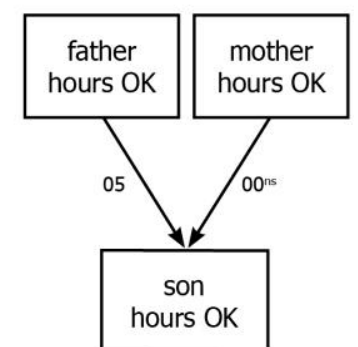

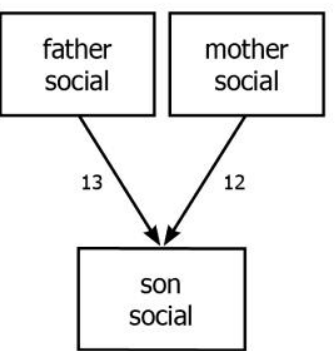

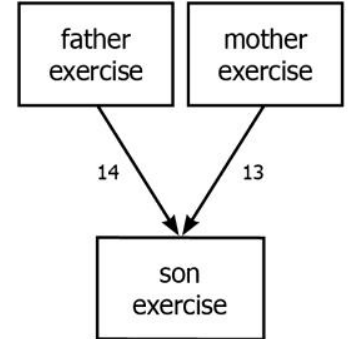

Measures of fit for the entire model:

LR test $\operatorname{chi}^{2}(308)=2147.08(\mathrm{p}<0.001)$

RMSEA $=0.03$

$\mathrm{CFI}=0.91$

$\mathrm{CD}=0.81$

stability index $=0.44$

Measures of fit for life satisfaction:

$\mathrm{mc}^{2}$ for father life satisfaction $=0.45$

$\mathrm{mc}^{2}$ for mother life satisfaction $=0.50$

$\mathrm{mc}^{2}$ for son life satisfaction $=0.20$

${ }^{a}$ Coefficients are significant at the 0.001 level unless marked n.s. not significant
Life Satisfaction

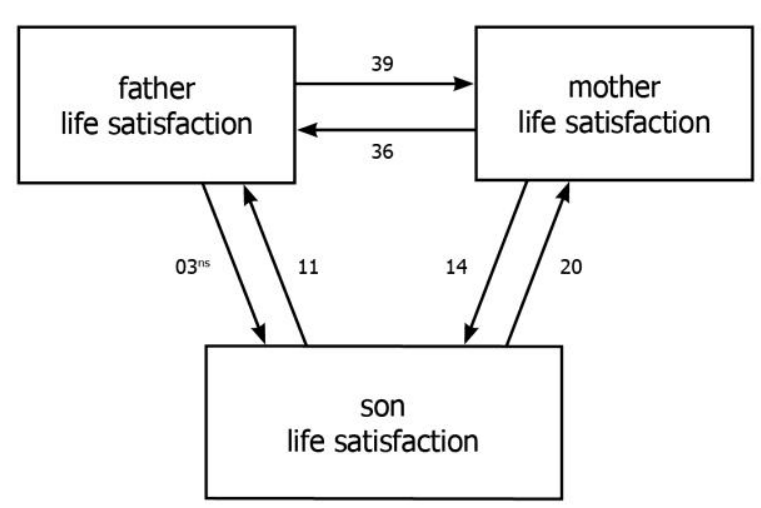


Figure 6: Parental Transmission of Values, Behavioral Choices and Life Satisfaction to Daughters (metric ML coefficients: $N=10440)^{a}$

\section{Values}

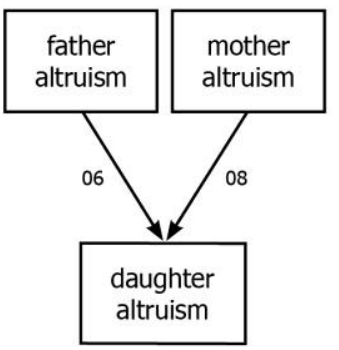

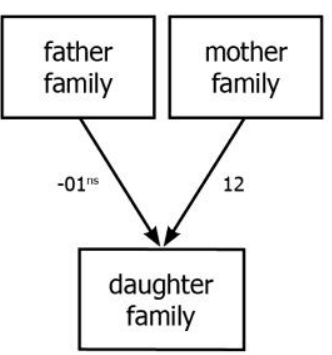

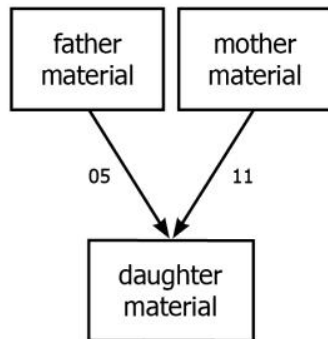

\section{Behavioral Choices}

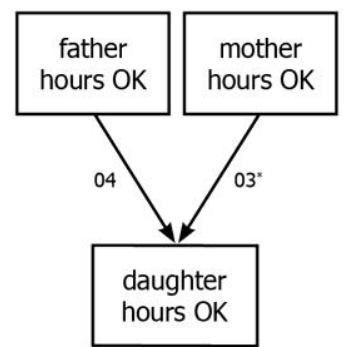

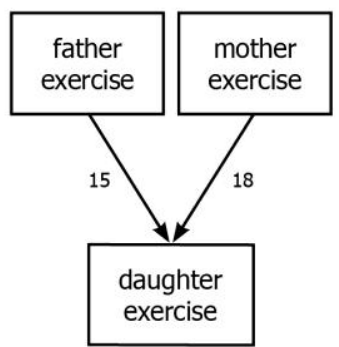

Measures of fit for the entire model:

\section{Life Satisfaction}

LR test $\operatorname{chi}^{2}(308)=2363.37(\mathrm{p}<0.001)$

RMSEA $=0.03$

$\mathrm{CFI}=0.91$

$\mathrm{CD}=0.80$

stability index $=0.40$

Measures of fit for life satisfaction:

$\mathrm{mc}^{2}$ for father life satisfaction $=0.44$

$\mathrm{mc}^{2}$ for mother life satisfaction $=0.46$

$\mathrm{mc}^{2}$ for daughter life satisfaction $=0.16$

${ }^{a}$ Coefficients are significant at the 0.001 level unless otherwise marked

* Significant at 0.05

n.s. not significant

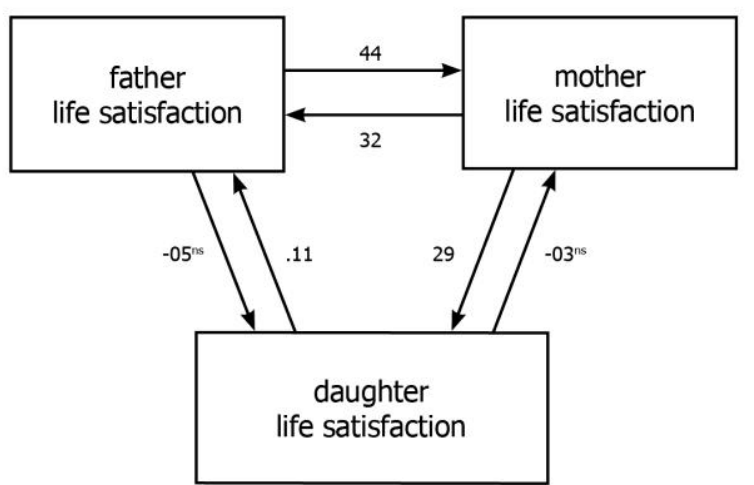




\section{University Library}

\section{- M M I N E R VA A gateway to Melbourne's research publications}

Minerva Access is the Institutional Repository of The University of Melbourne

Author/s:

Headey, B;Muffels, R;Wagner, GG

Title:

Parents Transmit Happiness Along with Associated Values and Behaviors to Their Children: A Lifelong Happiness Dividend?

\section{Date:}

2014-05-01

\section{Citation:}

Headey, B., Muffels, R. \& Wagner, G. G. (2014). Parents Transmit Happiness Along with Associated Values and Behaviors to Their Children: A Lifelong Happiness Dividend?. SOCIAL INDICATORS RESEARCH, 116 (3), pp.909-933. https://doi.org/10.1007/ s11205-013-0326-7.

Persistent Link:

http://hdl.handle.net/11343/282817 